\title{
Chemical composition of elephant grass silages supplemented with different levels of dehydrated cashew bagasse
}

\section{Composição químico-bromatológica de silagens de capim-elefante com diferentes níveis de bagaço de caju desidratado ${ }^{1}$}

\author{
Danillo Glaydson Farias Guerra²; Isaac Sydney Alves da Silva Maia ${ }^{3}$; \\ Alexandre Paula Braga ${ }^{4}$; Liz Carolina da Silva Lagos Cortes Assis; \\ Jesane Alves de Lucena ${ }^{4}$; Denise Cristiane Bidler ${ }^{5}$; \\ Clemente Fernandes dos Santos Neto ${ }^{6}$; Yonara Francisca Medeiros e Silva ${ }^{7}$; \\ Maria Izabel Batista Pereira ${ }^{8}$; Márcia Marcila Fernandes Pinto ${ }^{8}$
}

\begin{abstract}
The objective of the present study was to evaluate the chemical composition of elephant grass silages supplemented with different levels dried cashew bagasse (DCB). Our experiment used a randomized design replicated four times, each replicate consisting of the following five treatments: $100 \%$ elephant grass; $95 \%$ elephant grass $+5 \%$ DCB; $90 \%$ elephant grass $+10 \%$ DCB; $85 \%$ elephant grass $+15 \%$ DCB; and $80 \%$ elephant grass $+20 \%$ DCB. The elephant grass was cut manually to a residual height of $5 \mathrm{~cm}$ at 80 days of age, and cashew bagasse was obtained from the processing of cashew stalks used in fruit pulp manufacturing in Mossoró/RN. Plastic buckets were used as experimental silos, and 90 days after ensiling the experimental silos were opened and the contents analyzed. The addition of dried cashew bagasse to silage linearly increased the levels of dried matter and crude protein by $0.59 \%$ and $0.13 \%$, respectively, for each $1 \%$ addition $(\mathrm{P}<0.05)$. The neutral detergent fiber and acid detergent content of the silages was reduced by $0.22 \%$ and $0.09 \%$, respectively, for each $1 \%$ addition of the bagasse. The total carbohydrate content was not influenced by the bagasse addition ( $\mathrm{P}>0.05)$, and averaged $82.29 \%$. The levels of nonfiber carbohydrate showed linear growth $(\mathrm{P}<0.05)$ as the dehydrated cashew bagasse was added, and $\mathrm{pH}$ and ammoniacal nitrogen levels were reduced. The addition of the dehydrated bagasse to elephant grass silage improves its chemical composition, and it can be effectively added up to the level of $20 \%$.
\end{abstract}

Key words: Additive. Fermentation. By-product.

\footnotetext{
${ }^{1}$ Parte da dissertação do primeiro autor.

2 Discente do Curso de Doutorado do Programa de Doutorado Integrado em Zootecnia, Universidade Federal da Paraíba, UFPB, Campus da UFPB, Areia, PB, Brasil. E-mail: danilloglaydson@hotmail.com

${ }^{3}$ M.e em Produção Animal na Universidade Federal Rural do Semi-Árido, UFERSA, Mossoró, RN, Brasil. E-mail: isaacsydney10@ gmail.com

4 Profs. Drs., Dept ${ }^{\circ}$ de Ciências Animais, DCA, UFERSA, Mossoró, RN, Brasil. E-mail: apbraga@ufersa.edu.br; liz@ufersa.edu. br; jesane@ufersa.edu.br

5 Discente do Curso de Mestrado do Programa de Pós-Graduação em Zootecnia, Centro de Saúde e Tecnologia Rural, PPGZ/ CSTR, Universidade Federal de Campina Grande, UFCG, Campus de Patos, PB, Brasil. E-mail: bidlerzoo@hotmail.com

${ }^{6}$ Discente do Curso de Mestrado do Programa de Pós-graduação em Zootecnia, Universidade Estadual Vale do Acaraú, UVA/ Embrapa Caprinos e Ovinos, Sobral, CE, Brasil. E-mail: clementefernandes14_@hotmail.com

7 Discente do Curso de Graduação em Zootecnia, UFERSA, Mossoró, RN, Brasil. E-mail: yonaram@live.com

${ }^{8}$ Discentes do Curso de Mestrado do Programa de Pós-Graduação em Produção Animal, PPGPA, Universidade Federal do Rio Grande do Norte, UFRN/UFERSA, Mossoró/Natal, RN, Brasil. E-mail: maria.belly@hotmail.com; marcia_fernandesss@ hotmail.com

* Author for correspondence
} 


\title{
Resumo
}

\begin{abstract}
Objetivou-se com o presente estudo avaliar a composição químico-bromatológica das silagens de capim-elefante com diferentes níveis de adição de bagaço de caju desidratado. O experimento foi conduzido em delineamento inteiramente casualizado com cinco tratamentos que foram compostos pelas seguintes proporções: $100 \%$ capim-elefante; $95 \%$ capim-elefante $+5 \%$ de DCB; $90 \%$ capimelefante $+10 \%$ DCB; $85 \%$ capim-elefante $+15 \%$ de DCB e $80 \%$ de capim-elefante $+20 \%$ de DCB, com base na matéria natural e quatro repetições. O capim-elefante foi cortado manualmente a uma altura residual de $5 \mathrm{~cm}$ com 80 dias de idade, e bagaço de caju foi obtido do processamento dos pedúnculos de caju utilizados na fabricação de polpa de frutas em Mossoró/RN. Foram utilizados baldes plásticos como silos experimentais e 90 dias após a ensilagem os silos experimentais foram abertos e realizados análises. Observou-se que a adição do bagaço de caju desidratado na ensilagem aumentou linearmente $(\mathrm{P}<0,05)$ os teores de matéria seca e proteína bruta, em 0,59 e 0,13 pontos percentuais respectivamente para cada $1 \%$ de adição. Os teores de fibra em detergente neutro e fibra em detergente ácido das silagens foram reduzidos em 0,22 e 0,09 pontos percentuais respectivamente para cada $1 \%$ de adição do bagaço de caju desidratado na ensilagem. Os teores de carboidratos totais não sofreram influencia $(\mathrm{P}>0,05)$ com a adição do subproduto, com média de $82,29 \%$. Os teores de carboidratos não fibrosos foram influenciados $(\mathrm{P}<0,05)$ apresentando crescimento linear à medida que foi adicionado o bagaço de caju desidratado na ensilagem. As silagens apresentaram reduções do $\mathrm{pH}$ e nitrogênio amoniacal com adição do bagaço de caju desidratado. A adição do bagaço de caju desidratado ao capim-elefante para ensilagem melhora a composição químico-bromatológica. O bagaço de caju desidratado pode ser utilizado até o nível de 20\% na matéria natural.
\end{abstract}

Palavras-chave: Aditivo. Fermentação. Subproduto.

\section{Introduction}

The main forage resource for ruminant feed in Brazil has been tropical grasses, but supplies of grass exhibit qualitative and quantitative fluctuations throughout the year due to climatic factors, and this causes difficulties in farming. Conservation of forage as silage is a valuable approach to maintaining satisfactory production levels throughout the year (SILVA et al., 2010).

Elephant grass (Pennisetum purpureum Schum.) is an important forage plant that exhibits excellent annual production (POMPEU et al., 2006). Elephant grass does not make good silage, however, because of its high moisture content at the time of harvest and its low levels of the soluble carbohydrates that are required for the development of lactic acid bacteria during the fermentation process (LAVEZZO, 1994). As a result of these factors, there may be a loss of soluble nutrients in the form of wastewater because of the excess elephant grass moisture, and also a loss of nutrients in the form of gases generated by secondary fermentation, a process caused by spoilage microorganisms, mainly Clostridium bacteria, that develop in high humidity environments and produce ammoniacal nitrogen and butyric acid (ZANINE et al., 2006a).

To inhibit the growth of these undesirable microorganisms and minimize losses due to secondary fermentation, water-absorbing additives have been used containing dry matter and soluble carbohydrates (ZANINE et al., 2006b). Thus, the by-products of processing such fruits as acerola, cashew, passion fruit, and pineapple, among others, could play important roles in improving elephant grass silages (CRUZ et al., 2010).

In northeastern Brazil, especially in the states of Ceara, Rio Grande do Norte, and Paraiba, cashew cultivation is a socioeconomically prominent activity (ARAGÃO et al., 2007). However, this activity is geared mostly to the production of chestnut. A total of more than 265 tons of cashews are produced annually in the northeastern states, but less than $6 \%$ of the cashew peduncle is exploited by the food industry. 
According to Ferreira et al. (2004), are generated around $40 \%$ of waste in the industrialization of the cashew pseudo for the production of juices and pulps, and when the activity is mainly focused on exploration Chestnut, the waste generated rises to 90\% (HOLANDA et al., 1996). It is important to remember that cashew production is concentrated in the dry season, which is marked by a lower supply of food and consequently higher prices (PEREIRA et al., 2009).

Therefore, the aim of the present study was to evaluate the effects of different supplementary levels of dehydrated cashew bagasse on the chemical composition of elephant grass silage.

\section{Material and Methods}

Our experiments were conducted at the Animal Nutrition Laboratory (LANA) of the Universidade Federal Rural of the Semi-Árido (UFERSA) in Mossoró/RN, and they followed a randomized design replicated four times, each replicate consisting of five treatments made up of elephant grass (Pennisetum purpureum Schum.) and dehydrated cashew bagasse (Anacardium occidentale L.) (DCB) in the following proportions: $100 \%$ elephant grass (control); $95 \%$ elephant grass $+5 \%$ DCB; $90 \%$ elephant grass + 10\% DCB; $85 \%$ elephant grass $+15 \% \mathrm{DCB}$, and $80 \%$ elephant grass $+20 \%$ DCB.

The elephant grass was obtained on the farm of UFERSA, located in the district of Alto de São Manoel in Mossoró/RN in an area irrigated by flooding. It was cut manually to a residual height of $5 \mathrm{~cm}$ at 80 days of age. After harvesting, the grass was shredded in a mechanical shredder to obtain particles between 1 and $2 \mathrm{~cm}$. The cashew bagasse was obtained from the processing of cashews used in fruit-pulp manufacturing in Mossoró/RN. After the pressing process, the residue (cashew bagasse) was taken to a $100 \mathrm{~m}^{2}$ solar dryer located at UFERSA. The material was spread in thin layers and turned four times daily to ensure a uniform dehydration process. The dehydration process lasted from 48 to $72 \mathrm{~h}$ depending on weather conditions. After drying, the DCB was shredded again in a mechanical shredder to obtain smaller particles and to facilitate mixing with the elephant grass to be ensiled.

20 plastic buckets were used as experimental silos (five treatments and four repetitions), each with a height of $29 \mathrm{~cm}$, upper radius of $13 \mathrm{~cm}$, and lower radius of $14.5 \mathrm{~cm}$. The buckets were sealed with individual covers and taped to ensure a proper seal. An amount of $10.34 \mathrm{~kg}$ of material to be ensiled was established, so that the silage presented a density $600 \mathrm{~kg} / \mathrm{m}^{3}$. We weighed $10.64 \mathrm{~kg}$ material in the appropriate pre-determined proportions of elephant grass and DCB, and removed a sample of approximately $300 \mathrm{~g}$ that was placed in a labeled plastic bag and immediately taken to LANA to be greenhouse-dried by forced air at $55{ }^{\circ} \mathrm{C}$ for $72 \mathrm{~h}$ for further analysis; the rest $(10.34 \mathrm{~kg})$ was ensiled.

Experimental silos were opened 90 days after ensiling, the upper and lower portion of about $10 \mathrm{~cm}$ was discarded, and the rest of the silage discharged and homogenized in a plastic bag. Four samples were taken from each experimental unit for further analysis.

Ammoniacal nitrogen content $\left(\mathrm{N}-\mathrm{NH}_{3}\right)$ was measured as a percentage of total nitrogen (TN), following the methodology of Nogueira et al. (2005). The $\mathrm{pH}$ was measured with a digital $\mathrm{pH}$ meter. Analyses of dry matter (DM), crude protein (CP), ether extract (EE), organic matter (OM), neutral detergent fiber (NDF), acid detergent (ADF), and lignin (Lig) were performed following the methodology of Silva and Queiroz (2002). The cellulose content (Cel) was calculated as the difference between NDF and lignin. The levels of neutral detergent insoluble protein (PIND) and acid detergent (PIAD) were determined from residues of NDF and ADF by the micro Kjeldahl procedure. The hemicellulose levels (HCel) were calculated as the difference between the NDF and ADF content. The total carbohydrate (TC) and non-fiber carbohydrate 
(NFC) levels were estimated according to the methodology described by Sniffen et al. (1992). To estimate the total digestible nutrients (TDN) of both the original material and the silages we used the equations proposed by Weiss (1992), with the modifications suggested by the NRC (2001).

The data were subjected to analysis of variance and regression analyses. The choice of models was based on the significance of the linear and quadratic coefficients by the Tukey test at $5 \%$ probability.

\section{Results and Discussion}

The chemical composition of elephant grass and dehydrated cashew bagasse used in silage are shown in Table 1. The regression equations, determination coefficients, and coefficients of variation for the average percentage levels of the chemical components in the different silages are shown in Table 2 .
Some parameters can be used as indicative of good fermentation and good silage quality, including DM levels, the concentration of $\mathrm{N}-\mathrm{NH}_{3}$ as a percentage of total nitrogen (TN), and $\mathrm{pH}$ (VAN SOEST, 1994; PIRES et al., 2009).

In this study, the addition of dried cashew bagasse (DCB) linearly increased the levels of $\mathrm{DM}$ and reduced the $\mathrm{pH}$ of the silages $(\mathrm{P}<0.05)$. For the DM, this increase was estimated as $0.59 \%$ for each $1 \%$ addition of by-product (Table 2). The total increase in DM content was $23.92 \%$ and $35.27 \%$ for silage with $0 \%$ and $20 \%$ added DCB, respectively. This increase can be explained by the inclusion of by-product with higher MS levels than the elephant grass, as shown in Table 1. It was also observed that, proportionally, with the addition of $10 \%$ by-product, was reachead the DM level, which promotes a good fermentation process, between 30 and 35\% DM second McDonald et al. (1991).

Table 1. Chemical composition of elephant grass (Pennisetum purpureum Schum) and dehydrated cashew bagasse (Anacardium occidentale L.) used in silage.

\begin{tabular}{lcc}
\hline \multicolumn{1}{c}{ Nutrients } & Elephant Grass & Dehydrated Cashew Bagasse \\
\hline Dry matter $^{1}$ & 21.58 & 89.73 \\
Organic Matter $^{2}$ & 88.58 & 95.03 \\
Ethereal extract $^{2}$ & 1.69 & 3.44 \\
Crude Protein $^{2}$ & 5.58 & 15.54 \\
NDIP $^{2 *}$ & 1.95 & 13.18 \\
ADIP $^{2 *}$ & 1.25 & 11.92 \\
Neutral Detergent Fiber $^{2}$ & 72.63 & 53.68 \\
Acid Detergent Fiber $^{2}$ & 47.45 & 38.49 \\
Cellulose $^{2}$ & 38.82 & 21.12 \\
Hemicellulose $^{2}$ & 25.18 & 15.20 \\
Lignin $^{2}$ & 7.87 & 17.07 \\
Total Carbohydrates $^{2}$ & 81.31 & 79.95 \\
Non-Fibrous Carbohydrates $^{2}$ & 13.21 & 42.06 \\
Total Digestible Nutrients $^{2}$ & 55.37 & 55.75 \\
\hline
\end{tabular}

1 \% Fresh Matter; ${ }^{2} \%$ Dry Matter; ${ }^{*}$ Neutral Detergent Insoluble Protein; ${ }^{* *}$ Acid Detergent Insoluble Protein.

The DCB functioned to increase the DM good fermentation, and avoiding the possible content, creating favorable conditions for development of undesirable bacteria (Clostridium) 
that produce butyric acid (MACIEL et al., 2008). According to McDonald et al. (1991), DM content is one of the most important factors to be considered in silage because it maintains the nutritional value of conserved forage.

Ferreira et al. (2004) did not observe increases in DM content when cashew bagasse from the juice industry was used in the elephant grass silage process. Gonçalves et al. (2007), studying the addition of dried cashew peduncle to elephant grass silage and Brachiaria decumbens at levels of 0 , $5,10,15$, and $20 \%$ in $\mathrm{MN}$, observed increases in DM levels of $0.65 \%$ for each $1 \%$ addition of the dehydrated cashew peduncle.

Table 2. Regression equations, coefficients of determination $\left(\mathrm{R}^{2}\right)$, and coefficients of variation $(\mathrm{CV})$ for the average percentage levels of the chemical components of elephant grass silages with added DCB.

\begin{tabular}{lcccccccc}
\hline \multirow{2}{*}{ Variables } & \multicolumn{9}{c}{ Added DCB (\% FM) } & Regression Equation & \multirow{2}{*}{$\mathrm{R}^{2}$} & CV (\%) \\
\cline { 2 - 5 } & 0 & 5 & 10 & 15 & 20 & & & \\
\hline $\mathrm{DM}^{1}$ & 23.92 & 26.33 & 30.99 & 33.18 & 35.27 & $\mathrm{y}=24.03+0.59 \mathrm{x}$ & 0.97 & 4.92 \\
$\mathrm{OM}^{2}$ & 88.62 & 89.33 & 90.49 & 90.7 & 90.76 & $\mathrm{y}=87.17+0.13 \mathrm{x}$ & 0.98 & 0.89 \\
$\mathrm{EE}^{2}$ & 1.71 & 1.73 & 2.01 & 2.23 & 2.30 & $\mathrm{y}=1.70+0.04 \mathrm{x}$ & 0.94 & 13.36 \\
$\mathrm{CP}^{2}$ & 4.71 & 5.08 & 5.63 & 6.39 & 6.45 & $\mathrm{y}=4.69+0.10 \mathrm{x}$ & 0.96 & 5.68 \\
$\mathrm{NDIP}^{2}$ & 1.47 & 2.69 & 3.62 & 4.95 & 5.98 & $\mathrm{y}=1.48+0.23 \mathrm{x}$ & 0.99 & 8.07 \\
$\mathrm{ADIP}^{2}$ & 1.01 & 2.11 & 3.10 & 4.65 & 4.81 & $\mathrm{y}=1.10+0.20 \mathrm{x}$ & 0.96 & 8.47 \\
$\mathrm{NDF}^{2}$ & 72.03 & 71.98 & 70.32 & 69.07 & 68.03 & $\mathrm{y}=72.47-0.22 \mathrm{x}$ & 0.95 & 1.73 \\
$\mathrm{ADF}^{2}$ & 47.98 & 47.42 & 47.11 & 46.67 & 46.08 & $\mathrm{y}=47.97-0.09 \mathrm{x}$ & 0.98 & 2.3 \\
$\mathrm{HCel}^{2}$ & 24.05 & 24.56 & 23.21 & 22.4 & 21.95 & $\mathrm{y}=24.51-0.13 \mathrm{x}$ & 0.85 & 7.41 \\
$\mathrm{Cel}^{2}$ & 38.67 & 37.61 & 36.99 & 35.08 & 34.83 & $\mathrm{y}=38.67-0.20 \mathrm{x}$ & 0.95 & 2.45 \\
$\mathrm{Lig}^{2}$ & 7.88 & 8.47 & 8.57 & 9.30 & 9.40 & $\mathrm{y}=7.95+0.08 \mathrm{x}$ & 0.93 & 12.47 \\
$\mathrm{TC}^{2}$ & 82.21 & 82.51 & 82.84 & 82.08 & 82.02 & $\mathrm{y}=82.29$ & - & 0.76 \\
$\mathrm{NFC}^{2}$ & 14.05 & 15.55 & 18.02 & 20.08 & 21.71 & $\mathrm{y}=13.89+0.40 \mathrm{x}$ & 0.99 & 6.93 \\
$\mathrm{TDN}^{2}$ & 55.59 & 55.48 & 56.32 & 55.68 & 55.77 & $\mathrm{y}=55.79$ & - & 2.52 \\
\hline
\end{tabular}

$1 \%$ Fresh Matter; 2 \% Dry Matter.

The reduction in $\mathrm{pH}$ due to the inclusion of DCB in the silage (Table 3) may have occurred as a result of the increase in the content of DM and NFC (non-fiber carbohydrates), which favored the development of bacterial lactic acid and so contributed to the rapid decline in $\mathrm{pH}$ (SILVA et al.,
2010). The $\mathrm{pH}$ values set forth in the literature as suitable for silage are between 3.8 and 4.2, because those values indicate good fermentation and storage (MOTA et al., 2015). Thus, only the experimental silages made by adding $10 \%$ DCB can be considered within the optimal $\mathrm{pH}$ range.

Table 3. Mean values, regression equations, coefficients of determination $\left(\mathrm{R}^{2}\right)$, and coefficients of variation $(\mathrm{CV})$ of $\mathrm{pH}$ and ammoniacal nitrogen $\left(\mathrm{N}-\mathrm{NH}_{3}\right)$ levels in elephant grass silages with added DCB.

\begin{tabular}{|c|c|c|c|c|c|c|c|c|}
\hline \multirow{2}{*}{ Variables } & \multicolumn{5}{|c|}{ Added DCB (\% FM) } & \multirow{2}{*}{ Regression Equation } & \multirow{2}{*}{$\mathrm{R}^{2}$} & \multirow{2}{*}{ CV $(\%)$} \\
\hline & 0 & 5 & 10 & 15 & 20 & & & \\
\hline $\mathrm{pH}$ & 4.46 & 4.4 & 4.15 & 3.71 & 3.65 & $y=4.54-0.05 x$ & 0.93 & 5.12 \\
\hline $\mathrm{N}-\mathrm{NH}_{3}{ }^{*}$ & 10.32 & 9.54 & 7.86 & 4.74 & 4.05 & $y=10.77-0.35 x$ & 0.95 & 9.02 \\
\hline
\end{tabular}

*\% Total Nitrogen. 
The data described in this paper agree with the results of Barcelos et al. (2014) who studied elephant grass silage harvested at 70 days of age with different levels of added coffee pods; they found the $\mathrm{pH}$ decreased linearly with increasing coffee hull supplementation. Rêgo et al. (2010b), in a study of dehydrated cashew peduncle supplementation in elephant grass silage, observed increases in silage $\mathrm{pH}$ values.

Another parameter that helps to assess the quality

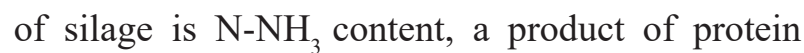
fermentation in ensiled material (BARCELOS et al., 2014). In this study the $\mathrm{N}-\mathrm{NH}_{3}$ levels in relation to total nitrogen $(\mathrm{TN})$ declined $(\mathrm{P}<0.05)$, with reductions from $0.35 \%$ for each $1 \%$ addition of DCB in the silage (Table 3). Reduction in ammoniacal nitrogen levels of $10.32 \%$ and $4.05 \%$ were observed with the addition of $0 \%$ and $20 \% \mathrm{DCB}$, respectively. Treatment with no additional DCB was very close to the ceiling of $10 \%$ of $\mathrm{N}-\mathrm{NH}_{3} / \mathrm{NT}$ recommended by Van Soest (1994) to classify the silages as good quality, exhibiting no excessive breakdown of protein into ammonia during the fermentation process.

Ammoniacal nitrogen is present in the green fodder at a concentration of less than $1 \% \mathrm{NT}$, and high values in silages are a reflection of intense proteolysis by enzymes of the plant itself or by Clostridium, resulting in compounds that reduce the efficiency of nitrogen use by rumen microorganisms. This process is reduced as there is a reduction in the $\mathrm{pH}$ of the ensiled material (SILVA et al., 2010).

The $\mathrm{pH}$ and $\mathrm{N}-\mathrm{NH}_{3}$ results alone are not sufficient to characterize good quality silage. The addition of DCB to silage proved effective in reducing those levels and thus reducing losses in silage derived from secondary fermentation.

Our results agree with those of Santos et al. (2008) who examined the inclusion of jackfruit in proportions of $0,5,10$, and $15 \%$ in elephant grass silage and found reductions of $8.7 \%$ in the $\mathrm{N}_{-} \mathrm{NH}_{3}$ levels, results that are not below the threshold referred to in the literature for well-fermented silages.

Crude protein content of elephant grass silage increased with the addition of DCB $(\mathrm{P}<0.05)$. For each $1 \%$ addition of the by-product there was an estimated increase of $0.10 \%$. There was an increase in $\mathrm{CP}$ content of $1.74 \%$ between no addition $(0 \%)$ and maximum addition (20\%) DCB treatments in elephant grass silage. Even with the highest addition level, the minimum CP content of 7\% suggested by Van Soest (1994) for good rumen function was not reached. Even so, the additive did significantly raise the CP levels of the silage. Rêgo et al. (2010a) studied the characteristics of elephant grass silages with inclusion of by-product of the mango in amounts of $0,4,8,12$, and $16 \%$, and they observed increases of $0.06 \%$ in $\mathrm{CP}$ content for each addition in $1 \%$ of the by-product.

Linear increases in NDIP and ADIP content were observed $(\mathrm{P}<0.05)$ in elephant grass silage as dehydrated cashew bagasse was added. For each $1 \%$ addition of the DCB, the NDIP and PIDA content increased 0.23 and 0.20 percentage points, respectively. This increase was because the DCB has higher levels of nutrients when compared to the elephant grass, as noted in Table 1.

ADIP and NDIP content is related to the availability of protein: the higher the content of these fractions, the less nitrogen is available to the animal, because the associated lignin, tannin, and Maillard compounds are highly resistant to microbial and enzymatic degradation, and ADIP considered unusable in both the rumen and the intestine (SNIFFEN et al., 1992).

As can be seen in Table 2, the NDF levels in elephant grass silage were influenced by the inclusion of DCB. For each $1 \%$ DCB addition, the NDF decreased by $0.22 \%$, with totals ranging from $72.03 \%$ to $68.03 \%$ for the $0 \%$ and $20 \%$ additionlevels, respectively. The data described in this study agree with the results of Cruz et al. (2010), who also observed a linear decrease in NDF of elephant grass 
silages as they added passion fruit peel to the silage.

The ADF content of the silages decreased linearly with increasing DCB addition $(\mathrm{P}<0.05)$. Every $1 \%$ added to the elephant grass silage resulted in a decrease of $0.09 \%$ in the ADF. The cell wall fraction is more difficult for animals to digest, and so high levels of ADF can compromise DM digestibility (VAN SOEST, 1994).

The Cel and HCel content decreased linearly with the addition of DCB $(\mathrm{P}<0.05)$. For each $1 \%$ addition to the elephant grass silage, we observed a decrease of $0.20 \%$ and $0.13 \%$ for $\mathrm{Cel}$ and $\mathrm{HCel}$, respectively. The DCB had lower $\mathrm{Cel}$ and $\mathrm{HCel}$ content than the elephant grass at the time of ensiling, justifying the reduction of these nutrients in the silages as the by-product was added.

Gonçalves et al. (2007) reported that there was a reduction in $\mathrm{HCel}$ content in elephant grass silage $(\mathrm{P}<0.05)$ with the addition of cashew apple. The values ranged from $31.56 \%$ with addition of $0 \%$ to $25.16 \%$ for the highest addition level $(20 \%)$. For each $1 \%$ addition of the cashew apple in the silage, the HCel levels were reduced by $0.32 \%$.

Unlike other cell wall constituents, Lig content showed a linear increase $(\mathrm{P}<0.05)$ as $\mathrm{DCB}$ was added. For each $1 \%$ addition, there was an increase of $0.08 \%$; total increases ranged from $7.88 \%$ to $9.40 \%$ for added DCB amounts of $0 \%$ and $20 \%$, respectively. This increase can be explained by the fact that the by-product used has higher Lig levels than the elephant grass (Table 1).

The total carbohydrate of the silage did not change with the addition of the DCB, and this may have occurred because the elephant grass and the by-product have similar total carbohydrate levels (Table 1). However, the NFC levels increased linearly with the addition of the DCB, rising $0.40 \%$ with each $1 \%$ addition. Total increases in NFC content ranged from $14.04 \%$ to $21.71 \%$ for DCB additions of $0 \%$ and $20 \%$, respectively. As noted in Table 1, the dehydrated cashew bagasse has CNF levels exceeding those of elephant grass, justifying the increased levels of this nutrient in the silage.

DCB addition did not influence $(\mathrm{P}>0.05)$ the TDN levels in elephant grass silage. This may have occurred because the TDN levels are similar in the ensiled materials, at $55.37 \%$ and $55.75 \%$ for elephant grass and DCB, respectively (Table 1). The TDN levels obtained in this study were lower than those found by Campos et al. (2010) from mathematical estimates of the energy value of forage $(63.84 \%, 57 \%, 57.53 \%$, and $57.94 \%$ TDN for sugar cane, elephant grass silage, corn silage, and sorghum silage, respectively).

\section{Conclusion}

The addition of dehydrated cashew bagasse to elephant grass silage improves chemical composition. It can be added up to the level of $20 \%$ of the total.

\section{References}

ARAGÃO, R. F.; ASINA, O. L. S.; GUEDES, A. M. Estudo experimental da secagem de fatias de caju. Alimentos Ciencia e Ingeniería, Ambato, v. 16, n. 3, p. 302-307, 2007.

BARCELOS, A. F.; CARVALHO, J. R. R.; TAVARES, V. B.; GONÇALVES, C. C. M. Valor nutritivo e características de silagem de capim-elefante com diferentes proporções de casca de café. Revista Eletrônica de Pesquisa Animal, Formosa, v. 2, n. 4, p. 186-200, 2014.

CAMPOS, P. R. de S. S.; VALADARES FILHO, S. de C. V.; DETMANN, E.; CECON, P. R.; LEÃO, M. I.; LUCCHI, B. B.; SOUZA, S. M. de; PEREIRA, O. G. Consumo, digestibilidade e estimativa do valor energético de alguns volumosos por meio da composição química. Revista Ceres, Viçosa, MG, v. 57, n. 1, p. 79-86, 2010.

CRUZ, B. C. C.; SANTOS-CRUZ, C. L.; PIRES, A. J. V.; ROCHA, J. B.; SANTOS, S.; BASTOS, M. P. V. Composição bromatológica da silagem de capimelefante com diferentes proporções de casca desidratada de maracujá (Passiflora edulis Sims f. flavicarpa). Revista Brasileira de Ciências Agrárias, Recife, v. 5, n. 3, p. 434440, 2010. 
FERREIRA, A. C. H.; NEIVA, J. N. M.; RODRIGUEZ, N. M.; LÔBO, R. N. B.; VASCONSELOS, V. R. Valor nutritivo das silagens de capim-elefante com diferentes níveis de subprodutos da indústria do suco de caju. Revista Brasileira de Zootecnia, Viçosa, MG, v. 33, n. 6, p. 1380-1385, 2004.

GONÇALVES, J. S.; NEIVA, J. N. M.; OLIVEIRA FILHO, G. S.; GONÇALVES, R. N. B. L. Valor nutritivo de silagens de capim-elefante (Pennisetum purpureum Shum) e Brachiaria decumbens contendo pedúnculo de caju (Annacardium occidentale L.) desidratado. Revista Brasileira de Zootecnia, Viçosa, MG, v. 38, n. 2, p. 204209, 2007.

HOLANDA, J. S.; FURUSHO, I. F.; LIMA, G. F. C.; NOBRE, F. V. Perspectiva do uso do pedúnculo de caju na alimentação animal. In: SIMPÓSIO NORDESTINO DE ALIMENTAÇÃO DE RUMINANTES, 6., 1996, Natal. Anais... Natal: Simpósio Nordestino de Produção Animal, 1996. p. 155-161.

LAVEZZO, W. Ensilagem de capim-Elefante. In: SIMPOSIO SOBRE MANEJO DE PASTAGENS, 10., 1994, Piracicaba. Anais... Piracicaba: ESALQ, 1994. p. 169-275.

MACIEL, R. P.; NEIVA, J. N. M.; OLIVEIRA, R. C.; ARAÚJO, V. L.; LÔBO, R. N. B. Características fermentativas e químicas de silagens de capim-elefante contendo subproduto da mandioca. Revista Ciência Agronômica, Fortaleza, v. 39, n. 1, p. 142-147, 2008.

McDONALD, P.; HENDERSON, A. R.; HERON, S. J. E. The biochemistry of silage. $2^{\text {th }}$ ed. Marlow: Chalcombe Publication, 1991. $340 \mathrm{p}$.

MOTA, P. E. S.; MOURA, R. L.; PORTELA, G. L. F.; CARVAlho, W. F.; OliveirA, M. R. A. Perdas e características fermentativas da silagem de capimelefante com diferentes aditivos. Revista Agropecuária Científica no Semiárido, Patos, v. 11, n. 1, p. 126-130, 2015.

NATIONAL RESEARCH COUNCIL - NRC. Nutrient requirements of dairy cattle. $7^{\text {th }}$ ed. rev. Washington, DC: National Academy of Sciences, 2001. 408 p.

NOGUEIRA, A. R. A.; CASTRO, A. L.; BERNARDI, C. R.; ZANOTTO, D. L.; SOUZA, G. B.; BARROCAS, G. E. G.; CARNEIRO, H.; LIMA, J. R.; FERREIRA, J. R.; MARTINI, M.; MARTINS, N. G.; FREITAS, S. C.; BEZERRA, V. S. Análise de alimentos. In: NOGUEIRA, A. R. A.; SOUZA, G. B. (Ed.). Manual de laboratórios: solo, água, nutrição vegetal, nutrição animal e alimentos. São Carlos: Embrapa Pecuária Sudeste, 2005. v. 1, p. 2001-2329.
PEREIRA, L. G. R.; AZEVEDO, J. A. G.; PINA, D. S.; BRANDÃO, L. G. N.; ARAUJO, G. G. L.; VOLTOLINI, T. V. Aproveitamento dos coprodutos da agroindústria processadora de suco e polpa de frutas na alimentação de ruminantes. Petrolina: Embrapa Semi-Árido, 2009. 30 p. (Embrapa Semi-Árido. Documentos, 220).

PIRES, A. J. V.; CARVALHO, G. C. P.; GARCIA, R.; CARVALHO JUNIOR, J. N.; RIBEIRO, L. S. O.; CHAGAS, D. M. T. Capim-elefante ensilado com casca de café, farelo de cacau ou farelo de mandioca. Revista Brasileira de Zootecnia, Viçosa, MG, v. 38, p. 34-39, 2009. Suplemento.

POMPEU, R. C. F. F.; NEIVA, J. N. M.; CANDIDO, O. M. J. D.; OLIVEIRA FILHO, G. S. Valor nutritivo de silagens de capim-elefante (Pennisetum purpureum Schum.) com adição de subprodutos do processamento de frutas tropicais. Revista Ciência Agronômica, Fortaleza, v. 37, n. 1, p. 77-83, 2006.

RÊGO, M. M. T.; NEIVA, J. N. M.; ANÍBAL, C. R.; CÂNDIDO, M. J. D.; CARNEIRO, M. S. S.; LÔBO, R. N. B. Chemical and bromatological characteristics of elephant grass silages containing a mango by-product. Revista Brasileira de Zootecnia, Viçosa, MG, v. 39, n. 1, p. 81-87, 2010a.

Chemical and bromatological characteristics of elephant grass silages with the addition of dried cashew stalk. Revista Brasileira de Zootecnia, Viçosa, MG, v. 39, n. 2, p. 255-261, 2010 b.

SANTOS, E. M.; ZANINE, A. M.; DANTAS, P. A. S.; DÓREA, R. R.; SILVA, T. C.; PEREIRA, O. G.; LANA, R. P.; COSTA, R. G. Composição bromatológica, perdas e perfil fermentativo de silagens de capim-elefante com níveis de inclusão de jaca. Revista Brasileira de Saúde e Produção Animal, Salvador, v. 9, n. 1, p. 64-73, 2008.

SILVA, C. F. P. G. da; PEDREIRA, M. dos S.; FIGUEIREDO, M. P. de; BERNARDINHO, F. S.; FARIAS, D. da H. Qualidade fermentativa e caracterização químico-bromatológica de silagens da parte aérea e raízes de mandioca (Manihot esculenta Crantz). Acta Scientiarum Animal Sciences, Maringá, v. 32, n. 4, p. 401-408, 2010.

SILVA, D. J.; QUEIROZ, A. C. Análise de alimentos: métodos químicos e biológicos. Viçosa, MG: Editora UFV, 2002. $235 \mathrm{p}$.

SNIFFEN, C. J.; O’CONNOR, J. D.; VAN SOEST, P. J.; FOX, D. G.; RUSSELL, J. B. A net carbohydrate and protein system for evaluating cattle diets. 2. Carbohydrate and protein availability. Journal of Animal Science, Champaign, v. 70, n. 11, p. 3562-3577, 1992. 
VAN SOEST, P. J. Nutritional ecology of the ruminant. $2^{\text {th }}$ ed. Ithaca: Cornell University Press, 1994. 476 p.

WEISS, W.P.; CONRAD, H.R.; PIERRE, N.R.S. A theoretically-based model for predicting total digestible nutrient values of forages and concentrates. Animal Feed Science and Technology, Amsterdam, v. 39, p.95-110, 1992.
ZANINE, A. M.; SANTOS, E. D.; FERREIRA, D. J.; OLIVEIRA, J. S.; PEREIRA, O. G. Avaliação da silagem de capim-elefante com adição de farelo de trigo. Archivos de Zootecnia, Córdoba, v. 55, n. 209, p. 75-84, 2006a.

ZANINE, A. M.; SANTOS, E. D.; FERREIRA, D. J.; PEREIRA, O. G.; CARVALHO, J. C. Efeito do farelo de trigo sobre as perdas, recuperação da matéria seca e composição bromatológica da silagem de capimmombaça. Brazilian Journal of Veterinary Research and Animal Science, São Paulo, v. 53, n. 6, p 803-809, 2006 b. 
